\title{
格子状街路網地区における経路の選択ならびに 探索に関する調査実験 PATH CHOICE IN GRID NETWORK OF STREETS
}

\author{
舟 橋 國男* \\ Kunio FUNAHASHI
}

\begin{abstract}
A questionnaire survey about residents' path choice and experiments on wayfinding performance of the first-time visitors in residential areas organized by rectangular grid streets have been executed. Two types of path choice behavior, i.e., "boundary walking" and "zigzag walking", and also characteristics and situation of each walking type are identified. These results are discussed with respect to the Garbrecht's model of random walking and random paths.
\end{abstract}

Keywords : path choice, wayfinding, behavior model 経路選択, 経路探索, 行動モデル

\section{1. 目的}

歩行者の経路選択傾向に関する既報文ににおいて，主 として交通駅舎などにおける群衆流の観測から, 目的地 に至る物理的に等価な 2 つの経路がある場合, それら経 路の利用には一定の偏りがあることを示した。

本研究はその発展の一方向として, 等距離複数経路群 とみなされる格子状街路網を有する住宅地を対象に, 環 境認知程度が高いと考えられる居住者の経路選択調查並 びに初来訪者による経路探索実験を行い，これら両結果 および格子状街路網における経路選択に関する Gar-

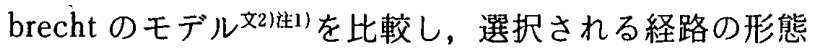
的特徴の側面から経路選択傾向の検討を行う。

\section{2. 居住者の経路選択調査}

2.1 方 法

（1）対象地区内の居住者に対し, 自宅之交通機関の最 寄り停留所 (以下 $\mathrm{ST}$ ) 間の歩行経路選択に関して質問 紙配票調查を行う。

（2）調查対象地：大阪市大正区内 $\mathrm{T}$ 地区，西宮市内 $N$ 地区の 2 力所 (図一 1$)$ 。 $\mathrm{N}$ 地区の ST は JR 駅舎, T地 区のST は市営バス停留所である。

(3) 調査対象者: 図一1のドット部に位置する各世帯 の中学生以上。配布回収状況は表一1のとおり。

(4) 質問項目: 居住者属性, 歩行頻度, 歩行目的, 歩 行経路 ( $1 / 3000$ の白地図に自記させる), 経路選択理由,

\section{距離認識。}

\section{2 結果と分析}

本調查では自宅から最寄り停留所 ST 入向かう歩行と その逆の带宅経路とを調查したが，前者を基礎として以 下の分析を行うこととし，自宅を出発点 $(\mathrm{Or})$ ，最初に 遭遇する交差点を「仮の出発点」(Or'), ST を目的点 (D) とする。

（1）利用交通の進行方向が歩行に与える影響 Or から ST への歩行が ST 以降の移動方向，つまり 「行き先」によって影響されることが考えられるのでこ の点について検討する。

(1) まずN地区の場合, 回答 83 例中 14 例が他と逆向き (下り列車利用) の行き先であるが，これら回答者の Or'が含まれる交差点 Kn 別に Or'-ST 間経路のパター ン種別とそれぞれの該当者数を表一2に一覧する。これ によると，いずれの Kn においても下り列車利用者の経 路パターンは，該当者の多い経路パターンに含まれてお り, その他の回答者の経路と特別に変わった傾向は認め られない。したがって，N地区居住者の場合，Or'-ST 間の歩行はそれ以降の移動方向とは関連せず，ST が自 立した目的地として完結した経路選択がなされていると

表一1 質問紙配布回収状況

\begin{tabular}{cccc}
\hline 地区 & 祀布效 & 有効回叹数 & 回收事 $(\%)$ \\
\hline T 地区 & 321 & 193 & 60.1 \\
N 地区 & 132 & 83 & 62.9 \\
\hline
\end{tabular}

本論文の一部は 1977 年度日本建築学会大会学術講演梗概集に「格子状街路網における経路選択に関する研究（No.5027)」として報告した。

*大阪大学工学部建築工学科 助教授. 工博 Assoc. Prof., Dept. of Architectural Engineering, Faculty of Engineering, Osaka Univ. Dr. Eng. 
考えられる。

(2) 次に T地区の場合, 図一1にもあるごとく利用され るST が 2 力所あり, 回答者の行き先, ST 選択ならび
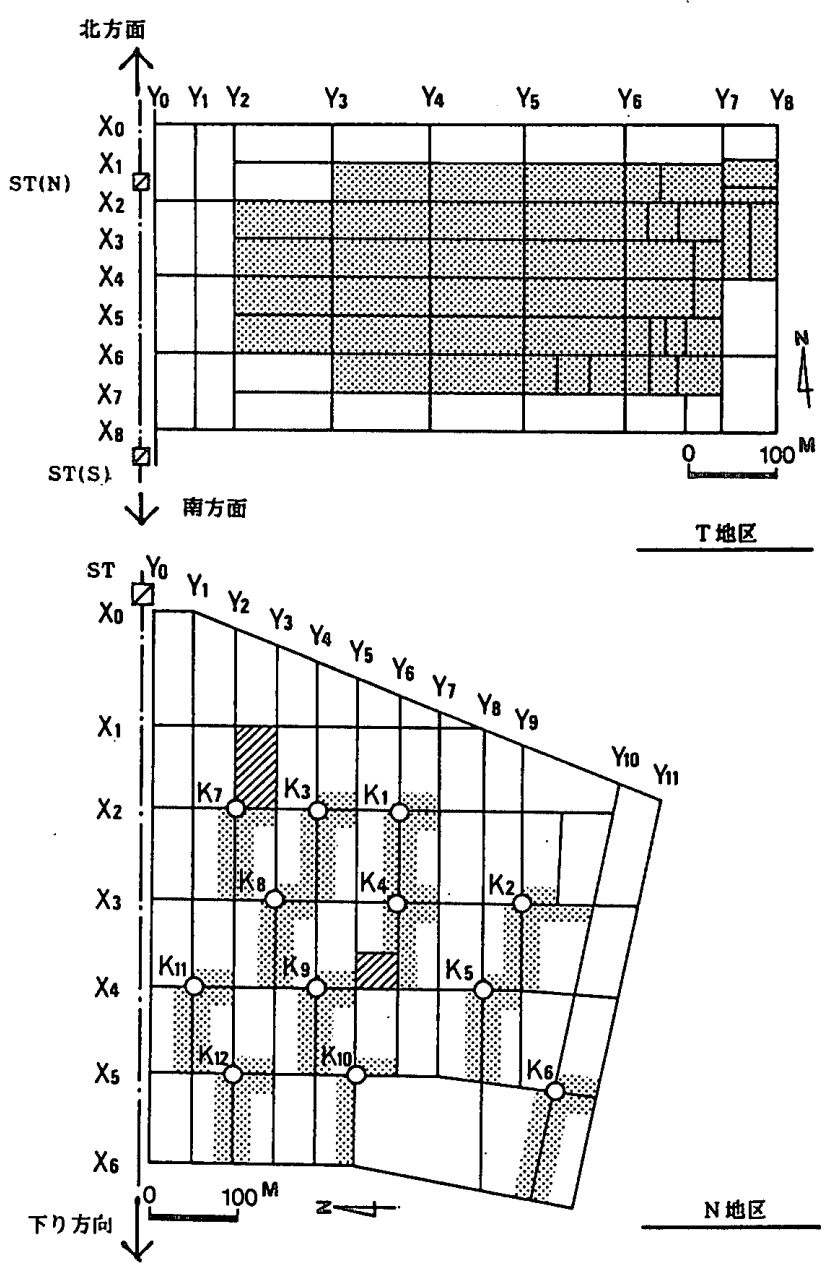

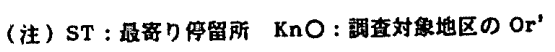
Q77: 公圆

図一1 調查地区概要

表一2 N 地区「下り利用者」を含む Or'からの経路パターン

\begin{tabular}{cccc}
\hline 交点 & バターン番易 & 跤当者数 & 「マク利用者」(内数) \\
\hline $\mathrm{K} 2$ & 1 & 7 & 1 \\
& 2 & 1 & 0 \\
\hline $\mathrm{K} 3$ & 1 & 4 & 2 \\
& 2 & 1 & 0 \\
\hline $\mathrm{K} 4$ & 1 & 2 & 1 \\
& 2 & 1 & 0 \\
& 3 & 1 & 0 \\
\hline $\mathrm{K} 5$ & 1 & 7 & 1 \\
& 2 & 1 & 0 \\
& 3 & 1 & 0 \\
& 4 & 1 & 0 \\
\hline $\mathrm{K} 6$ & 1 & 3 & 1 \\
& 2 & 1 & 0 \\
& 3 & 1 & 0 \\
\hline $\mathrm{K} 7$ & 1 & 5 & 2 \\
& 2 & 1 & 1 \\
& 3 & 1 & 0 \\
\hline $\mathrm{K} 8$ & 1 & 12 & 1 \\
& 2 & 3 & 1 \\
& 3 & 1 & 1 \\
& 4 & 1 & 0 \\
& 5 & 1 & 0 \\
& 6 & 1 & 0 \\
\hline $\mathrm{K} 9$ & 1 & 2 & 1 \\
& 2 & 1 & 0 \\
\hline $\mathrm{K} 11$ & 1 & 11 & 1 \\
& 2 & 1 & 0 \\
\hline
\end{tabular}

に経路選択が関連し合う可能性がある。この点について， まず，193 例中 16 例の「南方面行き」も図一-2に見るご とく対象地区内に一様に分布しているとみなされるの で,一括して全回答例の行き先とST 選択との関連をみ ると, 表一 3 のとおり有意な差は認められ家い。南方 面行き」 16 例中 ST $(\mathrm{N})$ を選択している 12 例について $\mathrm{N}$ 地区同様に，これら回答者の Or'が含まれる交差点別 にOr'-ST $(\mathrm{N})$ 間経路のパターン種別とその該当者を一 覧すると（表一4）, いずれの交差点においても「南方面 行き」回答者は全体として該当者の多いパターンに属し ており，他と特別に変わった経路パターンを示していな い。したがって，T地区においてもST 以降の行き先は

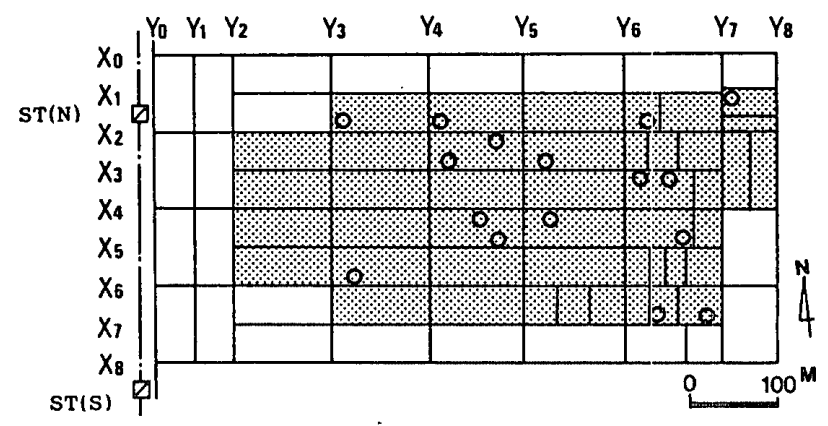

図一2 T地区「南方面行き」回答者の分布

表一3 T地区における行き先・ST 選択関連

\begin{tabular}{|c|c|c|c|c|}
\hline \multirow[b]{2}{*}{ 打 } & \multicolumn{3}{|c|}{ ST 通招 } & \\
\hline & $\mathrm{ST}(\mathrm{N})$ & $\mathrm{ST}(\mathrm{S})$ & 不定 & 到 \\
\hline 北方面 & 144 & 28 & 5 & 177 \\
\hline 南方面 & 12 & 3 & 1 & 16 \\
\hline it & 156 & 31 & 6 & 193 \\
\hline
\end{tabular}

表一4 T地区「南方面行き」を含む Or'からの経路パターン

\begin{tabular}{|c|c|c|c|}
\hline 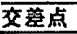 & バターン番导 & 䰚当老数 & 「南方面行き」内擞) \\
\hline \multirow[t]{3}{*}{$x 1 y 7$} & 1 & 1 & 1 \\
\hline & 2 & 1 & 0 \\
\hline & 3 & 1 & 0 \\
\hline \multirow[t]{2}{*}{$x 2 y^{3}$} & 1 & 5 & 1 \\
\hline & 2 & 1 & 0 \\
\hline \multirow[t]{3}{*}{$x 2 y 4$} & 1 & 2 & 1 \\
\hline & 2 & 1 & 1 \\
\hline & 3 & 1 & 0 \\
\hline$x 2 y 6$ & 1 & 8 & 1 \\
\hline \multirow[t]{2}{*}{$x 3 y 4$} & 1 & 11 & 1 \\
\hline & 2 & 2 & 0 \\
\hline \multirow[t]{3}{*}{$x 3 y 5$} & 1 & 5 & 1 \\
\hline & 2 & 4 & $\mathbf{0}$ \\
\hline & 3 & 3 & 0 \\
\hline$\times 3 y 6$ & 1 & 4 & 2 \\
\hline \multirow[t]{5}{*}{$x 4 y^{4}$} & 1 & 2 & 1 \\
\hline & 2 & 2 & 0 \\
\hline & 3 & 6 & 0 \\
\hline & 4 & 1 & 0 \\
\hline & 5 & 1 & 0 \\
\hline \multirow[t]{6}{*}{$x 4 y 5$} & 1 & 2 & 1 \\
\hline & 2 & 2 & 0 \\
\hline & 3 & 1 & 0 \\
\hline & 4 & 1 & 0 \\
\hline & 5 & 1 & $\mathbf{0}$ \\
\hline & 6 & 1 & 0 \\
\hline \multirow[t]{6}{*}{$x 5 y 4$} & 1 & 4 & 1 \\
\hline & 2 & 1 & 0 \\
\hline & 3 & 1 & 0 \\
\hline & 4 & 1 & 0 \\
\hline & 5 & 1 & 0 \\
\hline & 6 & 1 & 0 \\
\hline
\end{tabular}




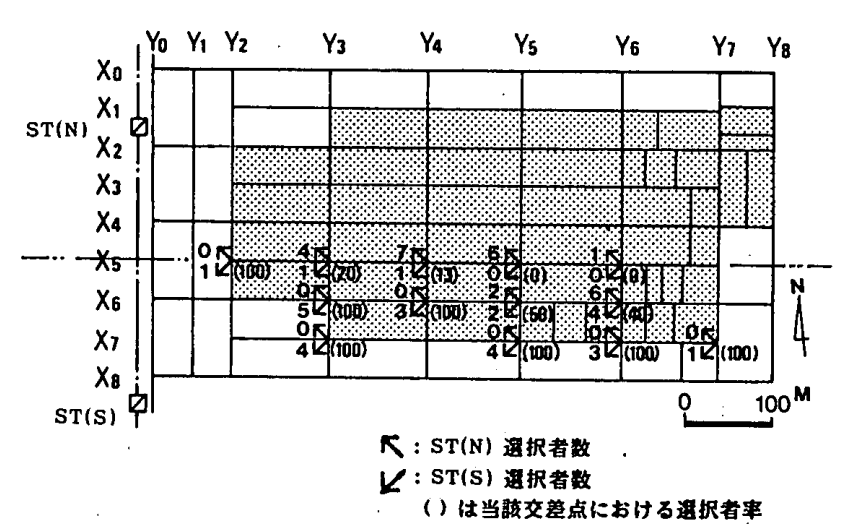

图一3 ST (S) 選択者分布

Or'-ST 間経路選択に関連せず，ST は自立した目的地 点としてとらえられ，それ自体で完結した選択として成 立しているといえよう。

以上から，以下の分析においては「行き先」にかかわ らず，Or'とST 間の経路だけを対象とする。

（2）T地区では，表一3に示されたとおり 2 力所ある $\mathrm{ST}$ のうち, 全体では $\mathrm{ST}(\mathrm{N})$ 選択者が多いが当然 $\mathrm{Or}$ ' とST (S) との位置関係によって選択傾向が変化する (図一3)。ST (S) 選択が見られるのは街路 X 5 以南に 限られ, かつ, 各 Or'別にはST のある y 0 から遠ざか るにつれて ST $(S)$ 選択者比率が低下する傾向が窥え, $\mathrm{ST}(\mathrm{N})$ 選択者の範井が 2 つの ST 間の等距離 2 等分線 を越えて ST $(\mathrm{S})$ 側にも広がっている。これはST(S) に比して ST (N) ならびにそれへの経路の方が選択され やすい性質を持っていることを意味している。全体とし て該当者の多い「北方面」行きの回答者の場合, ST (S) へは信号のある $\mathrm{x} 8$ および y 0 を横断するのに対し，ST (N) では横断歩道橋によって y 0 を横断するという差異 が影響しているのかも知れない。

（3）選択経路の分布について, Or'-ST 間の全経路分 布を図一4に示す。これによれば，Dを通る 2 本の境界 街路の一方に歩行が集中することがわかる。これは「D において，交通機関の軸に直交する街路」であり，ST へのメインアプローチとして機能しているといえよう。

（4）Or'-ST 間経路のタイプを，Or'における歩行方 向，および限界までの方向保持・途中変換の別により図 一 5 に示す 4 タイプに分類する。ここで，限界までの方 向保持とは境界街路（目的地への最短経路として迁回経 路にならない限界線）に至るまで歩行方向を保持する夕 イプを指す。

T地区 ST $(\mathrm{N})$ 選択者 (図一6-1)：Or'-ST 線之X 軸 のなす角度別に集計すると, 角度の増加にともないY夕 イプの歩行の比率が増加する。Yタイプ全経路数中 $\mathrm{Ye}$ が $86 \%$ を占めることから，x 2 まで歩行する経路が中 心である。Xタイプ中 y 0 まで直行する例は 2 例だけで ある。

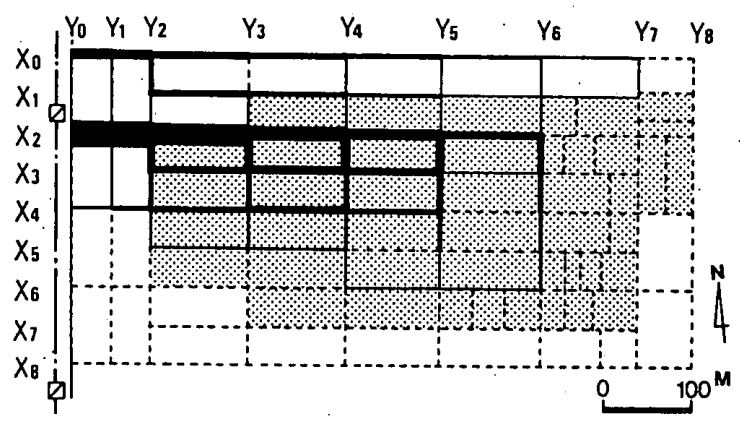

图一4-1 T 地区の ST $(\mathrm{N})$ 選択者

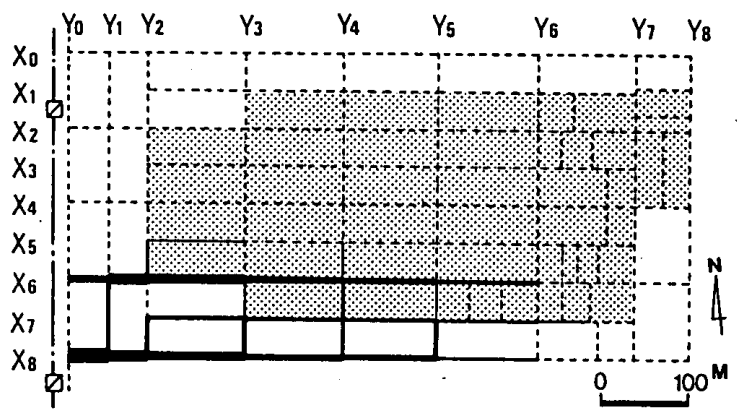

图一4-2 T地区の ST (S) 選択者

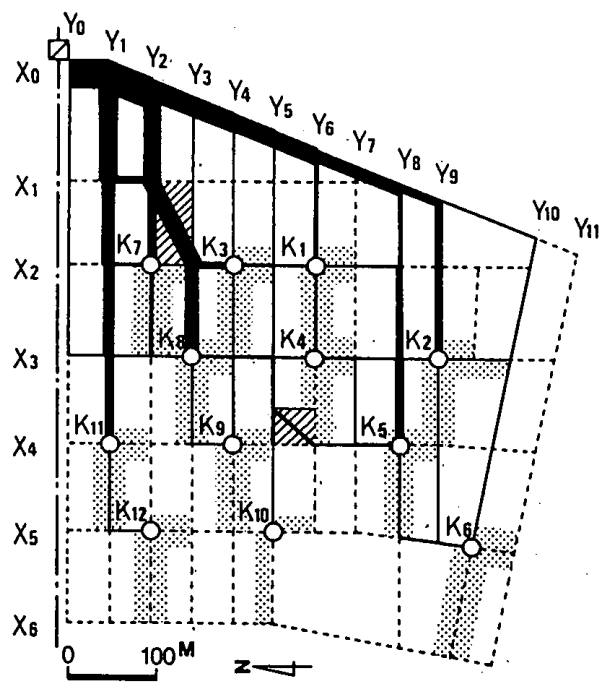

図-4-3 N 地区

図-4 Or'-ST 間経路分布

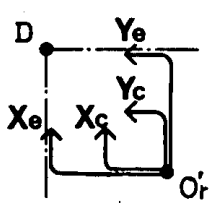

图一5Ｏr'における歩行方向と経路タイプ

$\mathrm{N}$ 地区（図一6-2）：同様に $\mathrm{x} 0$ 軸からの角度別に集計 すると，角度が大なるほどYタイプ歩行が増加する。た だし K 1，K 2 においてこの傾向が乱れているが、これ は斜行する 00 による短縮経路の影響と思われる。 00 が格子状グリッドに従っていれば K 1，K 2 の Y 夕イプ はより減少するものと予想される。ここでもYタイプ中 Ye が $70 \%$ を占める。Xe 経路はただ 1 例である。時間 短縮要素としての公園通り拔けと格子軸に対して斜行す 
る $\mathrm{x} 0$ を通る経路は，その要素が Or'-D 線上あるいはそ の近くに位置するほど選択されやすいといえる。

（5）Or'において，自宅（Or）からOr'までの歩行方 向をそのまま保持してゆくか方向変換するかを， Or-Or'間距離との関連でみる。住戸が集中している街 区の長辺リンクについてこれを 3 等分して比較すると (表一5)，N 地区ではOr-Or'の距離が長い歩行ほよ゙ Or'で方向変換が増加する傾向がみられるが，T地区で は差がない。また，両地区で全体傾向が逆転しているの は,メインアプローチの方向と街区の長辺方向との関係 による。つまり，T地区では街区の長辺方向がメインア プローチと平行しているので，これに向かうためにOr' での歩行方向変換が生じ, N地区ではメインアプローチ と街区の長辺方向とが直交しているので Or'での方向を 保持したまま直進することになるといえる。

（6）歩行目的による変化を見ると, 通勤通学以外の目 的を持つ相対的に歩行頻度の低いと思われる歩行者にお いて, 方向変換の少ない単純な経路の比率が増加してい る(表一6)。これは, 習慣性および時間的制約との関連 によるものと推定される。

（7）帰宅時の経路が外出時（自宅からSTへ）と異な る歩行例においては，州宅時経路はより単純化される傾 向にある (表一7)。経路選択変更理由には, 時間的余裕, 経路の明るさ, 安全性等が挙げられている。

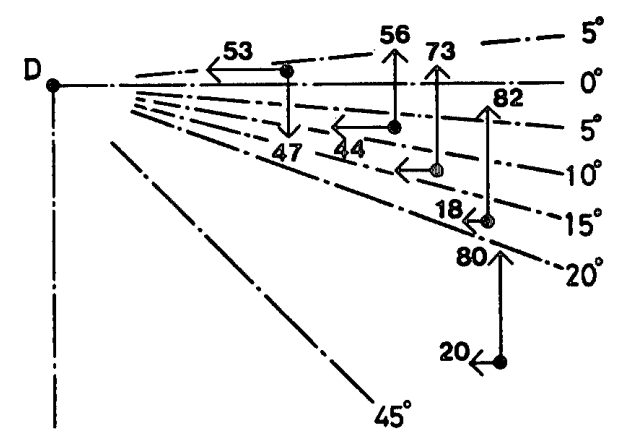

图一-1 T地区

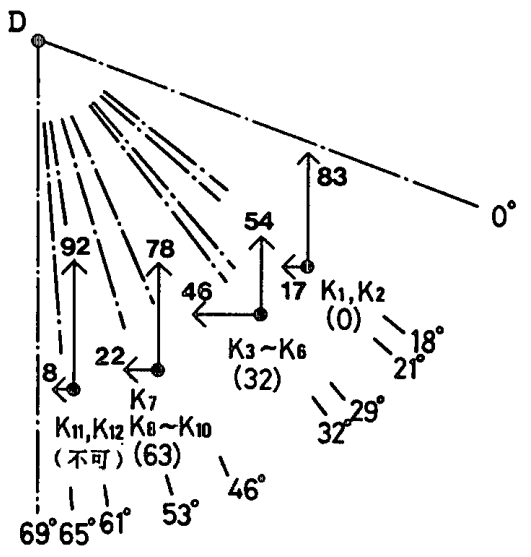

図一-2 N地区

（）：公園通り抜け発生率（％)

図一6 交差点位置別歩行経路タイプ比率
（8）次に各回答者の経路選択理由をみると，表一8の ごとく全体としてN地区で $49 \%$ が「最短距離」, $27 \%$ が「なんとなく」，T地区ではそれぞれ $35 \% ， 34 \%$ で あり，各地区ともこれら $2 つ$ つ理由で全体の 70〜75\% を占める。格子状街路網地区は物理的には「等距離」経 路からなるが，典型的な T地区の場合でも，ある経路を 選択したものの約 $1 / 3$ はそれを他の経路より「短い」「最 短」の距離と感じていることを意味する。一方で「なん となく」としか理由を特定できないものが全体の 1/4$1 / 3$ あり, 習慣的で意識化されにくい行動の性質も示さ れているものと思われる。以上から「最短絽路」を意識 的に選択するものと注2)，ほとんど「選択」を意識しな い行動とに大別されると理解され得よう。

実際に選択された経路の形態と選択理由との関連をみ ると，表一8に示したとおり，両地区とも任意方向変換 回数による理由の変化は認められない。なお両地区を比 較すると, 有意ではないが $\mathrm{N}$ 地区の「最短距離」が多い。

表一5 Or'における方向変換・保持傾向

\begin{tabular}{|c|c|c|c|c|}
\hline \multirow[t]{2}{*}{$\langle\mathbf{N}$ 地区 } & \multicolumn{4}{|c|}{ 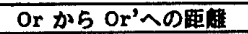 } \\
\hline & 帛 & 中 & 近 & 䀘 \\
\hline 方向登提 & 5 & 5 & 4 & 14 \\
\hline & 38 & 28 & 17 & 100 \\
\hline 万向保持 & 8 & 13 & 19 & 40 \\
\hline \% & 62 & 72 & 83 & 100 \\
\hline it & 13 & 18 & 23 & 54 \\
\hline
\end{tabular}

\begin{tabular}{|c|c|c|c|c|}
\hline \multirow[t]{2}{*}{ 〈T地区 } & \multicolumn{4}{|c|}{ Or かE Or'べの更 } \\
\hline & 通 & 中 & 近 & 骮 \\
\hline 方向㘴推 & 17 & 46 & 19 & 82 \\
\hline & 63 & is & 63 & 100 \\
\hline 方向保特 & 10 & 21 & 11 & 42 \\
\hline x & 37 & 31 & 37 & 100 \\
\hline 能 & 27 & 137 & 30 & 124 \\
\hline
\end{tabular}

表一 6 歩行目的と任意方向変換回数!

\begin{tabular}{|c|c|c|c|c|c|c|}
\hline \multicolumn{2}{|c|}{ 任慧方向安搭（回） } & 0 & 1 & 2 & $3 \sim$ & 例数 \\
\hline \multirow[t]{2}{*}{ T地区 } & 通䵢·通学 & $23 x$ & 62 & 6 & 9 & 130 \\
\hline & その他目的 & $46 \%$ & 50 & 4 & 0 & $-\overline{28}$ \\
\hline \multirow[t]{2}{*}{ N地区 } & 通䓵·通学 & $59 \%$ & 15 & 25 & 22 & 68 \\
\hline & モの他目的 & 71 & 7 & 14 & 7 & $\overline{14}$ \\
\hline
\end{tabular}

表一7 䚻宅時経路の任意方向変換回数增诚

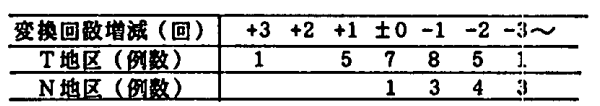

表一8 外出時経路の選択理由（複数回答）

\begin{tabular}{|c|c|c|c|c|c|}
\hline & $\begin{array}{l}\text { 任礁方向 } \\
\text { 变势 }\end{array}$ & 菆短厓田 & なんとなく & モの他 * & 碚 \\
\hline \multirow[t]{2}{*}{$\mathrm{N}$ 垉区 } & $\begin{array}{l}0 \text { 回 } \\
1 \text { 回 } \\
2 \text { 回以上 }\end{array}$ & $\begin{array}{r}20 \\
5 \\
23\end{array}$ & $\begin{array}{r}13 \\
3 \\
10\end{array}$ & $\begin{array}{r}12 \\
0 \\
11\end{array}$ & $\begin{array}{r}45 \\
8 \\
44\end{array}$ \\
\hline & 盽 & $48(49)$ & $26(27)$ & $23(24)$ & $97(100)$ \\
\hline \multirow[t]{2}{*}{ T 地区 } & $\begin{array}{l}0 \text { 回 } \\
1 \text { 回 } \\
2 \text { 回以上 }\end{array}$ & $\begin{array}{r}36 \\
28 \\
5\end{array}$ & $\begin{array}{r}24 \\
36 \\
7\end{array}$ & $\begin{array}{r}21 \\
32 \\
8\end{array}$ & $\begin{array}{l}81 \\
96 \\
20\end{array}$ \\
\hline & 㼛 & $69(35)$ & $67(34)$ & $61(31)$ & $197(100)$ \\
\hline
\end{tabular}

\#「モの他」は、安全、曲がるのがおっくう、钢分がよい远、矮。 （）内は百分比を示す。

表一-9 N地区距離短縮要素を含む経路と選択理旺（複数回答）

\begin{tabular}{|c|c|c|c|c|}
\hline 释路の㡺的 & 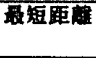 & なんとなく & モの他 & 郃 \\
\hline Y e & 22 & 12 & 12 & 46 \\
\hline 公图通り菠け & 18 & 5 & 5 & 28 \\
\hline その他 & 8 & 9 & 6 & 23 \\
\hline 辟 & $48(49)$ & $26(27)$ & $23(24)$ & $97(100)$ \\
\hline
\end{tabular}

*「モの佨」は、安全、曲がるのがおっくう、気分がよい禗、學。 （）内は百分比を示す。 
この理由として, 公園通り抜けならびにメインアプロー 于 $(\mathrm{X} 0)$ の斜行という物理的な距離短縮要素が意識さ れている故と想定され得るが, 表一9によると, 上記距 離短縮要素を含む経路とそれ以外の経路との間に経路選 択理由の有意な差は認められない。このように，実際に 選択されている経路の形態的特徵と居住者による選択の 理由づけとには明確な関連性は認められない。

\section{3. 初来訪者経路探索実倹}

\section{1 実験方法}

（1）実験対象地とその周辺を訪れたことのない被験者 に所定の目的地まで歩行させ，経路の選択（探索）状況 を調べる。

（2）・実験地は T地区内に，2 種類のグリッド E 1(260 $\mathrm{M} \times 140 \mathrm{M})$ および $\mathrm{E} 2(350 \mathrm{M} \times 100 \mathrm{M})$ を設定する（図 $-7)$ 。

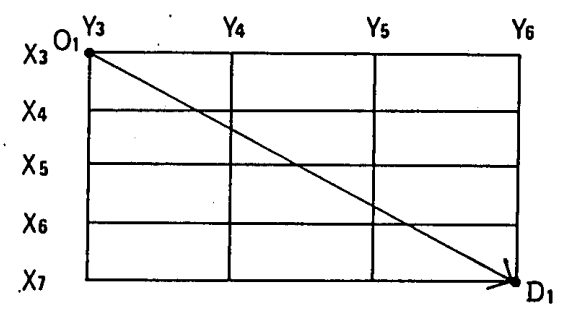

グリッド $\mathrm{E} 1$

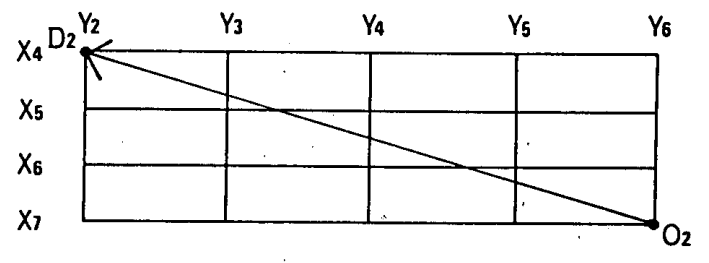

グリッドE2

図一7 経路探索実験グリッド

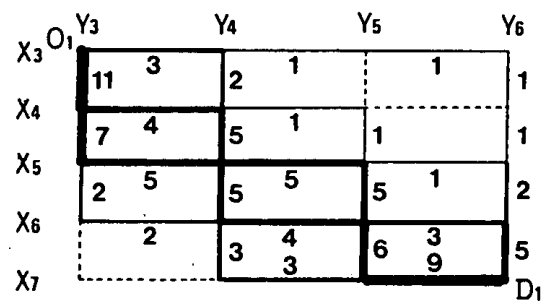

図-8-1 経路探索歩行実験結果 (A-E 1)

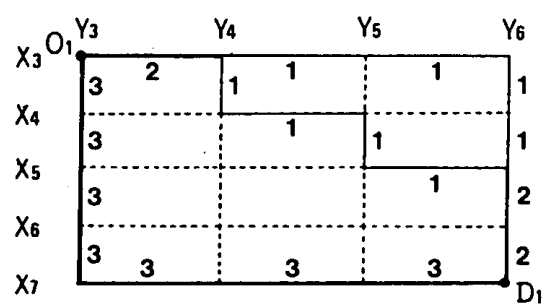

図一8-3 経路探索歩行奏験結果 (B-E 1)
（3）被験者は実験地を初めて来訪する神戸地区在住学 生 19 名。教示方法の異なる A B B 2 群に分ける。A群 14 名には出発交差点 $(O)$ において目的交差点 (D) への 距離を口頭で伝えるとともに，方向を指差する。B群 5 名には出発交差点において実験地の白地図 $(1 / 2500)$ を 20 秒間学習させる。

（4）目的交差点中央には目標となる人物（被験者の友 人）を立たせ, '境界街路上に至れば目的地点を見通して 認知できるようにする。

\section{2 結果亡分析}

被験者の選択経路分布を図一8に示す。

$\mathrm{A}$ 群 : $\mathrm{E} 1, \mathrm{E} 2$ とも格子状グリッドの O-D 間対角線 方向沿いの階段状経路選択が多い。被験者は，指示され た方向と距離から想定される目的の位置を目指しつつ, 直交する $2 つ$ つ街路のいずれかを採って出発し, 交差街 路に至れば右 (左) 方向を見通して目標の存否を探査す る。ここで目標が発見されないとき, 進行してきた街路 をそのまま直進するか, 対角線に漸近するように右 (左) 折するか, が選択される。この場合被験者には, 街路構 成を中心とする地区環境に関する情報が欠如しており， これを市街地街路構成に関する一般的知識による想像で 補うしかないから, 所与の方向・距離による目的地の空 間的定位にも確信が得られ難い。そこで, 対角方向に目 標物があるという意識から同一街路上の直進を長く続け ず，かつ，指示された方向から想定される対角線を大き く踏み越えないよう右左折を繰り返す探索方法を採るも のと考えられる。その結果, O-D 間対角線によって 2 分される領域のうち, 出発時に採った側の領域内にとど まりながら対角線に潮近することになり, 対角線沿い階 段状経路選択とはいえ，O-D 間対角線を踏み越えるこ とは少なくなる。

$\mathrm{O}$ 点出発時にいずれの側を採るかについて，E 1 の

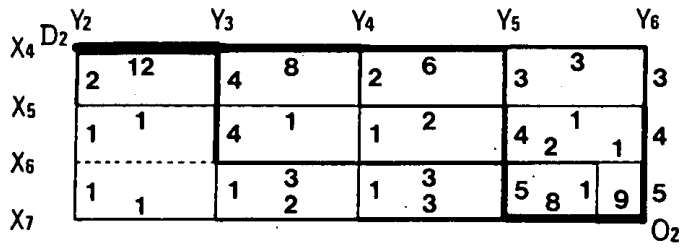

図-8-2 経路探索歩行実験結果 (A-E 2)

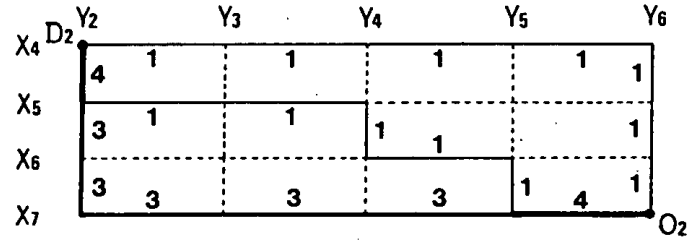

図一8-4 経路探索歩行実験結果 (B-E 2)

図一8 経路探索歩行実験結果 
1 では南北方向街路の y 3 に集中し, E 2 の 02 では東 西方向街路の $x 7$ への出発が多い。この差異について,

E 1 では指示方向が x 3 街路から約 30 度方向であったの に対し，E 2 では $\mathrm{x} 7$ から約 15 度で $\mathrm{x} 7$ 沿いに目標が定 位されたのかも知れない。なお，実験後のインタビュー によれば，教示された距離は有効な情報として活用され ていないが, 交差点ごとの目標物確認という比較的単純 な探索方法においては距離情報を必要としていない。以 上, 歩行は目的方向指向的特徵を示すといえる。

$\mathrm{B}$ 群：E1，E 2 とも境界線上歩行である。被験者は 白地図学習により, 地区の街路構成と出発 -目的交差点 間の空間的関係とを把握し, 目的交差点の空間的定位が 相対的に容易であり, 所与の課題地点間に関する限りは 居住者に準ずる環境認知程度に近づくと想定されよう。

いずれにも 1 例だけ階段状経路選択者がいるがこの被 験者は地図学習に際し, 東西 1 リンクと南北 1 リンクの 組合せを単位行動としその繰り返しと修正の付加として 目的地までの経路を読み取っている。

O点からの出発方向は目的点に至るまでに通過すべき 交差点数の多い側が選ばれている。2次元的な移動を必 要とするとき, まず記憶された交差点数の多い方を処理 しようとする傾向にあるものと了解される。歩行は街路 空間の軸性に影響されているものと思われる。

\section{4. 考察}

4.1 典型的な歩行経路

以上の分析によると, 街路が格子状をなす場合, 交通 機関の持つ軸性に直交する方向にメインアプローチが発 生し,メインアプローチおよびそれを含む境界線上歩行 が主に選択される傾向が確認された。同様の指摘は Marchand, B. 嚆にもみられ, 出勤時の自宅 $\rightarrow$ 駅舎間歩 行において, 歩行者は, 最短距離経路でなく, 最適経路 (most agreeable) でもなく, かつ安全でなくても, 最 も単純なパスを選んでまず近くの主要軸へ向かい, まっ

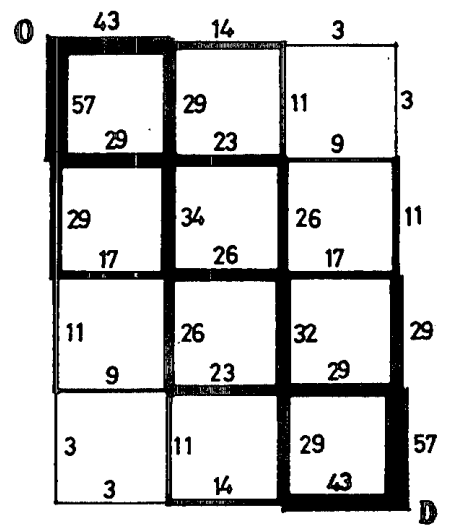

図一9-1 Garbrecht のモデルによる歩行者数分布 (3リンク X4 リンクのグリッド・Random Path の場合) (数值は歩行者数 100 名としたときの各経路通過者数)
すぐこれに沿って進む，と述べている。ただし，本調査 によれば歩行目的や時間的制約の変化によって対角線沿 いの階段状歩行も発生する。経路形態の決定にはOr'-D 線の方向認識と街路の軸性のなす角度が影響している。 すなわちXあるいはYタイプの歩行の発生率は Or'-D の位置に対応して変化するといえる。

これらの結果から，格子状街路網における歩行経路の 典型例として, 境界線上歩行と階段状歩行があるといえ， それぞれの特徴を表一10のようにまとめることが出来 よう。

初来訪者の経路探索実験によれば, 地区の環境認知水 準が相対的に高いと想定されるB群被験者が境界線上歩 行を示して，居住者の基本的な経路選択傾向に類似して おり，環境認知水準の低いA群被験者は，想定される対 角線に漸近するよう右左折を繰り返す結果として階段状 歩行を示す。環境を熟知し目的地を定位し得てフレキシ ブルな選択行動が可能である居住者もまた，歩行目的や 状況によって目的地への指向性が強い場合には，前述の とおり階段状歩行を採ることがあり，環境詒知水準の低 い初来訪者の探索行動之形態的に類似する点興味深い。

\section{2 ランダムモデルの検証}

ここで実験に用いた 3 リンク×4リンクの格子状グ リッドに Garbrecht のモデルを当てはめてみると図一9 のようになり，両モデルともO-D 間対角線に沿って歩 行量の分布が集中し境界線上の各コーナ一部は少ない。

\section{表一10 格子状街路網における歩行経路の典型}

\begin{tabular}{|c|c|c|c|}
\hline \multicolumn{2}{|c|}{ 妼行縤路タイプ } & 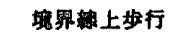 & 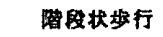 \\
\hline \multirow[t]{3}{*}{ 性叟 } & 方向 & 行酃の方向 & Dへの方向づけ \\
\hline & 支㔭紫 & 街路の粗性 & Or-Dの性 \\
\hline & 当西の目标 & メインアプローチ & 目的点 (D) \\
\hline \multirow[t]{2}{*}{ 条件 } & 照证性 & 㜊い & 强い \\
\hline & 時闰的的知 & 暍い & 强い \\
\hline
\end{tabular}

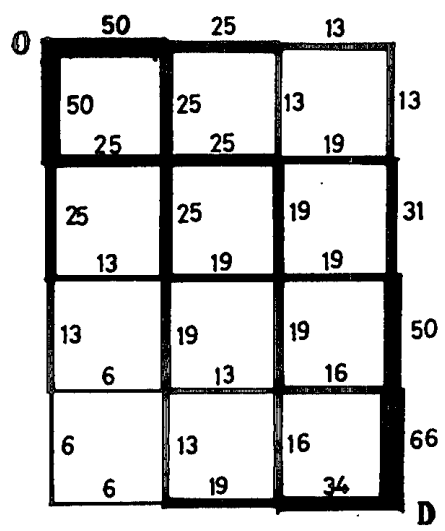

図一-2 Garbrecht のモデルによる歩行者数分布 (3リンク×4リンクのグリッド・Random Walk の場合) (数値は歩行者数 100 名としたときの各経路通過者数) 
これらのモデルでは, 歩行者は目的点の位置を含む経路 全体構造を把握しているとの前提が含意されており，そ の点では居住者の経路選択の場合に条件が類似している にもかかわらず, 先に分析した居住者の経路選択に特徴 的な境界線上歩行が表現されておらず，むしろ探索行動 のような, 目的指向性の強い階段状歩行の結果に相似し ている。

この点をさらに調べると，A群被験者が各交差点で選 択を繰り返す点でランダムウオークの仮定に近いけれよ゙ も，実験結果（図一8）にはモデルが想定するような選 択の対称性（図一9）はみられず，特にスタート地点で は一方の街路への偏りがモデルよりも著しい。したがっ て,一応は出発点で与えられた方向指示の影響も含めて, 交差点における選択は等確率には行われていないと判断 される。またB群については，与えられた地図上ですべ ての経路を学習可能ではあるが，実際には記憶の容易さ から境界線上経路が把握されているようであり，すべて の経路パターンの等確率選択というランダムパスの前提 にも合致しない。

さらにまた，図一8-1 と図一8-2 とを比較すると，E 1 ・E 2 という街路網全体の形状の差による実験結果の 差がみられ，また居住者の経路選択においても，Or'-D 線と境界線とのなす角度によってX・Yタイプの発生率 に影響したが，このような形状の性質について，このう ン゙ダムモデルには含まれていない。

以上のごとく, Garbrecht のモデルは実際の経路選択 を十分には表現し得ていない点がある。

\subsection{Garbrecht によるモデル修正の試み}

すでに Garbrecht 自身が，グリッド状に駐車された矩 形の屋外駐車場を，条件づけられていない環境 (uniform environment）と見立て，ここを対角線方向に通り抜け る歩行者の経路を観察した研究において，次のような傾 向を見いだしてランダム仮説の修正を示唆する解釈を試 みている文!。

すなわち，その一つは，「境界線上にとどまる」 (boundary persistance) 傾向で, 出発地を通る境界上 で分岐路に出会ってもそのまま境界線上を進む確率が， その境界線を離れて内側 (bounded area) へ歩いて行 く確率よりもはるかに高い。第二には，出発地と目的地 とをつなぐ対角線上，またはその近くの分岐路では，最 初に歩き始めた時の側にとよ゙まる。つまり，対角線の右 側へスタートした歩行者は対角線の右側にとどまり続け る。

これら傾向の解积として以下の推論を加えている。出 発地から目的地へ向けて見当づけられる対角線は，実際 には利用されないにもかかわらず，思いの中の方向づけ (imaginary curve) として歩行中ずっと意識されてお り，境界線に沿って進むことはこの思いの中の方向づけ
に対する近似となっている。境界線を離れて，中へ入る 時もこの方向づけに従う限りやはり対角線の近似であ り, 踏み越えれば, “迂回”之意識される。歩行者の行動 準拠枠は，一つの矩形なのではなく，対角線で分けられ た三角形のうちの一つなのであろう，と。

\section{4 まとめと今後の課題}

Garbrecht のランダムモデルは調査・観察結果と適合 しない。また，観察結果に対する上述の推論では，imaginary curve の存在とそれへの近似という仮説に立ち， すべての傾向を imaginary curve の影響に帰している が，その妥当性はいまだ確認されていない。本論では， 表一10にみるごとく，境界線上歩行は“意識されている imaginary curve への近似”というより，むしろ街路の 軸性に支配され方向付けられた結果であり，一方，目的 地へ直接方向付けられた場合に OD 間対角線に沿う階 段状歩行が生じやすく，それも一つの歩行経路選択型で あるとの解秎を仮説的に提示したい。

以上本論で行った分析は, 最も単純な幾何学的パ夕一 ンとしての格子状街路網における経路の選択という，日 常的な人間行動の傾向を出発・目的点間経路形態の側面 から特徵付け，歩行行動自体の内的特性の理解を試みよ うとするものであった。これに対して，一般的に選択行 為が選択対象の効用に影響されるところから，例えば街 路幅員・路面の装備・沿道施設等経路の物理的構造が経 路選択に一定の効用をもたらすものと想定し，その立場 から経路の物理的要因之選択との関連を解明しようとす る研究もみられる(43)。このような外的な要因の影響の あり方ならびに本論で述べた選択行動傾向との関連等も 今後の課題の一つとして残されている。

注

1）格子状街路網において引き返しや地区の境界 (boundary) を踏み越すような迁回はないと仮定した上で，行動のラ ンダム性を前提として,ランダム経路 (random paths) かランダム歩行 (random walk) かの，いずれかによる 選択がなされるとする。前者は, 出発地と目的地との閒 のすべての経路が等しい確率で選択されるもの, 後者は, 遭遇する交差点ごとにその地点のすべての交差路が等確 率で選択されるものである。

2）しかし「最短距離」を理由としたものも，いくつかの経 路の認知的な距離比較によって「短い」と判断された経 路を選んでいるというより，「迁回していない」という意 識からそれを「最も近い経路」と判断していることも考 えられる。この点は今後別途の確認を要する。

3）文5）にそれらの概要をまとめている。

\section{参考文献}

1）紙野桂人，舟橋國男：群衆流動にみられる空閂的定位の 傾向について, 日本建築学会論文報告集, 第 217 号, pp. $45 \sim 51,1974$. 
2) D. Garbrecht: Frequency distributions of pedestrian in a rectangular grid. Journal of Transport Economics and Policy, Vol. IX (1): pp.66 88, 1970.

3) B. Marchand:Pedestrian traffic planning and the perception of the urban environment : a French example. Environment and Planning A, Vol.6, pp.491 507, 1974.
4) D. Garbrecht: Pedestrian paths through a uniform environment. Town Planning Review, Vol.42( 1 ), pp. 71 -84, 1971.

5）紙野桂人，舟橋國男：都市空間と歩行者の経路選択， IATSS Review, Vol. 10, No. 5, pp. 323 329, 1984.

(1990 年 12 月 7 日原稿受理, 1991 年 8 月 8 日採用決定） 